\title{
Dariusz Wołczecki, Il sacerdote come mistagogo dell'Eucaristia. Ricerca spirituale sulla mistagogia liturgica alla luce dell'insegnamento di Giovanni Paolo II, Roma 2012, ss. 389
}

Wieloraka posługa Kościoła, a więc Ludu Bożego Nowego Przymierza, zadana przez samego Jezusa Chrystusa, niesie w sobie szerokie bogactwo ewangelizacyjne. Ma w nim określone i zarazem niepowtarzalne miejsce kapłaństwo chrzcielne. Nie mniej także kapłaństwo sakramentalne, inaczej zwane hierarchiczne jest także wyjątkowo twórczo wpisane w dzieła Kościoła. Zapewne m.in. dlatego problematyka kapłańska jest szczególnie wyraźnie wpisana we współczesna refleksję teologiczną. Wielość publikacji i opracowań jest wręcz imponująca.

Trzeba jednak zauważyć, że dynamika kapłaństwa ma także swój wyraz duchowy. Nie może ono być sprowadzone tylko do fizycznie dostrzeganych znamion. Stąd wydaje się naturalnym, że szerokie zainteresowania z zakresu teologii duchowości są także żywo obecne, a nawet przynoszą nowsze interesujące wyniki badawcze. Ta otwartość wiąże się oczywiście z wieloletnim nauczaniem Jana Pawła II, który pozostawił w tej kwestii ogromną spuściznę, która jest jednocześnie ważnym znamieniem nadziei.

Prezentowaną książkę otwiera wykaz skrótów, tak bibliograficznych jak i innych (s. 3-5) oraz metodologiczne wprowadzenie (s. 7-18). Z kolei całość materiału podzielono na pięć zasadniczych rozdziałów. Wydaje się, że warto choćby schematycznie wskazać na poszczególne elementy.

Jan Pawet II jako inspirator mistagogii liturgicznej $w$ postudze kapłańskiej to tytuł pierwszego rozdziału prezentowanej książki (s. 19-90). Najpierw przeanalizowano i doprecyzowano dwa terminy: mistagogia i mistagog. Ważne jest także rozeznanie samej metody mistagogicznej, zwłaszcza w odniesieniu do liturgii. $\mathrm{Na}$ tej bazie podjęto wstępne badania nad mistagogią w nauczaniu Jana Pawła II. 
Sprawozdania i recenzje

Kolejny rozdział opatrzony został tytułem Korzenie mistagogii u Jana Pawła II (s. 91-149). Na czoło wybijają się motywacje teologiczne i pastoralne. Przeanalizowano znaczenie mistagogii i jej powiązania z Kościołem pierwotnym. Wskazano na swoiste figury mistagogów takich jak: św. Ambroży, św. Cyryl Jerozolimski, św. Jan Chryzostom, św. Teodor z Mopsuestii oraz św. Maksym Wyznawca. To podprowadza do wskazania na aktualność mistagogii liturgicznej w Kościele współczesnym.

Autor zaprezentował następnie Źródta mistagogii liturgicznej Jana Pawta II (s. 151-224). Mistagogia jawi się jako wprowadzenie w misterium Chrystusa poprzez Eucharystię. Stąd sprawujący Eucharystię ukazany został jako mistagog. Kończąc rozdział autor, wskazał na warunki autentycznej mistagogii liturgicznej.

Czwarty rozdział studium Dariusza Wołczeckiego ukazuje Wkład formacyjny Jana Pawta II jako mistagoga celebracji Eucharystii (s. 225285). Cała formacja kapłańska winna mieć charakter mistagogiczny: powinna dotyczyć edukacji liturgicznej oraz formacji ludzkiej, duchowej, intelektualnej i permanentnej. Także życie kapłańskie powinno być swoistą „formą eucharystyczną”. W tym wszystkim wybrzmiewa wymiar praktyczny życia duchowego kapłana - mistagoga. W tym kontekście Maryja staje się niejako „Kobietą eucharystyczną”.

Aplikacje duszpasterskie mistagogii eucharystycznej Jana Pawła II to tytuł ostatniego rozdziału (s. 287-345). Kapłan - mistagog jest oddany posłudze prowadzącej do przeżywania doświadczenia misterium Chrystusa. Autor podkreśla, jak ważnym jest stosowanie mistagogii eucharystycznej w ciągu całego roku liturgicznego.

Całość treściową omawianej książki zamyka interesujące podsumowanie (s. 347-354). Następnie dodano jeszcze stosunkowo obszerną bibliografię (s. 355-383) oraz dość interesujący spis treści (s. 385-389).

W książce twórczo wybrzmiewa współczesny obraz kapłaństwa hierarchicznego, nakreślony bardzo szeroko zwłaszcza poprzez analizę bogatego piśmiennictwa Jana Pawła II. To nauczanie jest niezwykle twórczym z zarazem inspirującym źródłem dla dalszych badań naukowych. Papieskie przesłanie tchnie wielkim zaufaniem oraz nadziejami. Nie dziwi zatem, że autor podjął się analizy tej problematyki i umiejętnie sięga do tego nauczania w toku prowadzonych badań naukowych.

Nadanie proponowanym badaniom charakteru teologii duchowości, czyni omawianą wrażliwość kapłańską jeszcze bardziej dynamiczną i zarazem autentyczną, co zresztą jest szczególnym oczekiwaniem współczesności. Wnikanie w tę sferę musi, wręcz ze swej natury, czynić z niej realizm życia i apostolskiego zaangażowania w nową 
ewangelizację. Ona zaś jest szerokim doświadczeniem zobowiązań ewangelicznych. Odnosi się to szczególnie do posługujących w Kościele, a więc prezbiterów.

Przejście do sfery mistagogii liturgicznej nadaje całej duchowości interesującą optykę. Liturgia pozostaje bowiem szczególnym wyrazem podstawowych znamion Kościoła, oczywiście obok przepowiadania i świadectwa miłości caritas. Analiza problematyki mistagogii, tak w wymiarze teologicznym jak i duszpasterskim, prezentowania w studium Wołczeckiego, jest interesującą propozycją, choć wymaga jeszcze dalszych, bardziej szczegółowych analiz badawczych. Tym bardziej, że te dwa faktory jakby spotykają się praktycznie i życiowo właśnie w liturgii.

Dobrze, że w prezentowanej książce kapłaństwo wybrzmiewa $\mathrm{w}$ nachyleniu mistagogicznym, zwłaszcza ku Eucharystii. Przecież mistagogia sakramentalna jest ważnym narzędziem przepowiadania misteriów Chrystusa, a jeszcze szerzej - wielorakim bogactwem wiary, także charyzmatycznym. Co więcej, wybrzmiewa tutaj także wyraźniej całe Misterium Paschalne, a ono przecież jest centrum całego dzieła zbawczego, także tego trwającego w Kościele. W tym wszystkim musi być dostrzegana prawda osobowa człowieka, jako konkretnego indywiduum. W to wpisane jest także, zwłaszcza ze strony kapłanów, nieustanne składanie z Chrystusem i przez Niego duchowych ofiar swego powołania oraz dążenia do świętości.

Prezentowane opracowanie nosi zdecydowane znamiona pracy dyplomowej. Zresztą, oficjalnie zostało to także zaznaczone na stronie tytułowej. Widać tę specyfikę w samej organizacji treści jak i w ich formułowaniu. Studium to jest jednak dobrą podstawą dla uzyskania stopnia doktora teologii w zakresie teologii duchowości. Instytut Duchowości na Papieskim Wydziale Teologicznym „Teresianum”, na którym przedstawiono rozprawę, ku temu w szczególny sposób inspiruje swoją specyfiką, co więcej, daje także odpowiednie podstawy naukowo-badawcze.

Dobrze, że wśród przywoływanych nazwisk w odniesieniach bibliograficznych znajdują się polscy liturgiści oraz wielu innych uczonych, np. B. Nadolski, H. Witczyk, S. Czerwik, W. Świeżawski, H. Sobeczko, M. Mokrzycki. Wskazywano także chętnie na polskie słowniki, np. Leksykon liturgii, Encyklopedia chrześcijaństwa czy Leksykon duchowości katolickiej. Wskazywane są także liczne polskojęzyczne dzieła zbiorowe, poświęcone problematyce liturgicznej. Jest to wyjątkowo liczna rodzina wybitnych polskich uczonych, chętnie przywoływana w rozprawie. Wydaje się to ważnym i cennym elementem, aby 
w rozprawach naukowych publikowanych poza granicami Polski zapoznawać czytelników z polskojęzycznym dorobkiem naukowym. To jest wręcz obowiązek polskich autorów. Niestety takiej postawy nie spotyka się zbyt często.

Interesujące są konkluzje poszczególnych rozdziałów oraz podsumowanie całego studium. Taki zabieg jest ważnym elementem formalnym. To ostatnie zawiera bowiem także uwagi krytyczne oraz dalsze wskazania badawcze, które zawsze wskazuje się w pracy dyplomowej. Wskazano jednak także pewne dość dojrzałe uwagi podsumowujące i zarazem rezultaty przeprowadzonych badań, a zwłaszcza wkład we współczesną teologię duchowości. Jednocześnie nakreślono pewne ogólne dalsze propozycje czy nadal otwarte problemy badawcze. ważne uchwycenie jeszcze jednego interesującego nurtu jego przepowiadania oraz życia i świadectwa. Bogactwo odniesień do tego sakramentu wskazuje na szczególne rozeznanie powołania kapłańskiego, o którym tak wiele mówił, także ze swego kapłańskiego, biskupiego i papieskiego doświadczenia. Trudno bowiem je widzieć i analizować bez tego ożywczego źródła i znaku żywotności oraz trwania, jakim jest Eucharystia. Spotkanie obu sakramentów wybrzmiewa w tej pracy szczególnie twórczo: jeszcze raz potwierdzone zostaje, jak bogate i oryginalne jest nauczanie Jana Pawła II. Warto zatem do niego ciągle sięgać. 